Uniwersytet Jagielloński

Błażej Mądrzycki

Wyższa Szkoła Menedżerska w Warszawie

\title{
KONTROWERSJE DOTYCZĄCE OBIEKTYWNEJ PRZYCZYNY LEŻĄCEJ PO STRONIE PRACODAWCY JAKO PODSTAWY UZASADNIAJĄCEJ ZAWARCIE NIELIMITOWANEJ TERMINOWEJ UMOWY O PRACE
}

\author{
Abstract \\ Controversies regarding an objective reason on the part of the employer as the basis \\ justifying the conclusion of an unlimited fixed-term contract of employment
}

The legislator has provided four exceptions from the rule of limited period of employment based on a fixed-term contract and a limit on the total number of contracts, modeled on existing solutions in European law and dictated by market realities. These relate to target contracts, i.e. contracts for replacement work, part-time, seasonal employment, term of office in employment, and the most controversial case of objective reasons for the employer. In relation to these contracts, neither a time limit nor a quantitative limit is applied, and in the literature they are referred to as unlimited, objectively justified or specific contracts. With the proviso that the conclusion of a contract for a definite period must serve to meet the employer's demand for work, which is both real and periodic. In addition, when concluding a fixed-term contract justified by objective reasons, the employer remains obliged to notify the relevant district labor inspector - within 5 days - in electronic or written form about the conclusion of such a contract and indication of the reason for its conclusion. Violation of this obligation is an offense against the employee's rights. The application of the general clause by the legislator provides flexibility, but may also result in the of abuse by the employer. Therefore, the existence of objective reasons justifying the conclusion of a fixed-term employment contract will be subject to the assessment of the labor court in cases regarding the establishment of a legal relationship concluded on the basis of an employment contract for an indefinite period.

Słowa kluczowe: umowa na czas określony, obiektywne przyczyny leżące po stronie pracodawcy, umowy nielimitowane, brak limitów czasowych i ilościowych

Key words: fixed-term contract, objective reasons on the part of the employer, unlimited contracts, lack of time and quantity limits 


\section{Wprowadzenie}

W art. $25^{1} \S 4$ pkt 4 Kodeksu pracy (kp) ustawodawca wskazuje „obiektywne przyczyny" jako wyjątek uzasadniający odejście od reguły, której celem jest zapobieganie nadużyciom w stosowaniu umów o pracę na czas określony. Legislator, posługując się zwrotem ogólnym, niedookreślonym, postąpił inaczej niż w przypadku pozostałych okoliczności ${ }^{1}$, których zaistnienie umożliwia odejście od ogólnej zasady zawierania umów terminowych. Stosując w tym miejscu klauzulę generalną, ustawodawca po części dopuszcza szeroki wachlarz możliwych odstępstw, z drugiej strony wprowadza nieostre ograniczenie w postaci obiektywnych przyczyn leżących po stronie pracodawcy. Tak szeroko ujęty wyjątek wymaga od interpretatora ustalenia, jakie przyczyny można uznać za obiektywne w kontekście omawianej regulacji. Na marginesie warto zaznaczyć, że dekodowanie oczekiwanego przez ustawodawcę sposobu pojmowania „obiektywnych przyczyn" może być o tyle większym wyzwaniem w teorii i praktyce stosowania prawa, że ustawodawca - jak się wydaje - próbując dookreślić obiektywność przyczyn leżących po stronie pracodawcy, użył kolejnych klauzul generalnych². Na pojemność tych pojęć i związane z tym problemy w zakresie wykładni, a wręcz niemożliwość ich sprecyzowania, wskazywał już Sąd Najwyższy w opinii w sprawie rządowego projektu ustawy o zmianie ustawy Kodeks pracy oraz niektórych innych ustaw z dnia 15 maja 2015 r. ${ }^{3}$

Dla przejrzystości dalszych rozważań warto przytoczyć w tekście treść przedmiotowej regulacji, zgodnie $\mathrm{z}$ art. $25^{1} \S 4$ pkt $4 \mathrm{kp}$ :

Przepisu $\$ 1$ [wskazującego granice czasowe i ilościowe zawierania umów na czas określony - przyp. autorów] nie stosuje się do umów o pracę zawartych na czas określony: w przypadku gdy pracodawca wskaże obiektywne przyczyny leżące po jego stronie - jeżeli ich zawarcie w danym przypadku służy zaspokojeniu rzeczywistego okresowego zapotrzebowania i jest niezbędne w tym zakresie w świetle wszystkich okoliczności zawarcia umowy.

Celem zacytowania przepisu było ukazanie całości regulacji, aby przy pełnej świadomości jego treści można było następnie poddać ją analizie czy też ewentualnej ocenie.

1 Pozostałe okoliczności zostały wymienione w punktach od 1 do $3 \mathrm{w}$ art. $25^{1} \S 4 \mathrm{kp}$ i są to:

1) zastępstwo pracownika w czasie jego usprawiedliwionej nieobecności w pracy;

2) wykonywanie pracy o charakterze dorywczym lub sezonowym;

3) wykonywanie pracy przez okres kadencji.

2 Tak więc zgodnie z art. $25^{1} \$ 4$ pkt 4 „Przepisu $\$ 1$ [tj. ograniczenia czasowego i ilościowego dotyczącego umów na czas określony - przyp. autorów] nie stosuje się do umów o pracę zawartych na czas określony: w przypadku gdy pracodawca wskaże obiektywne przyczyny leżące po jego stronie - jeżeli ich zawarcie w danym przypadku służy zaspokojeniu rzeczywistego okresowego zapotrzebowania i jest niezbędne w tym zakresie w świetle wszystkich okoliczności zawarcia umowy”.

3 Opinia w sprawie rządowego projektu ustawy o zmianie ustawy - Kodeks pracy oraz niektórych innych ustaw Sadu Najwyższego Biura Studiów i Analiz z dnia 15 maja 2015 r., http://orka.sejm.gov.pl/ Druki7ka.nsf/0/EF78323E83FAD463C1257E4D002211D7/\%24File/3321-003.pdf (dostęp: 31.03.2018). 
Nie budzi wątpliwości to, że przyjęte przez ustawodawcę rozwiązanie zapewnia z jednej strony pracodawcom duży stopień elastyczności, ale z drugiej sprawia, że przy zastosowaniu tak wielu ogólnych klauzul może stworzyć pracodawcy spore problemy praktyczne. Wynika to $\mathrm{z}$ tego, iż ustawodawca posługuje się wieloma zwrotami nieostrymi, które mogą powodować problemy interpretacyjne. Co należy bowiem rozumieć przez „rzeczywiste” zapotrzebowanie? Wyłącznie takie, które jest realne i faktyczne oraz obiektywnie występuje? Z kolei „okresowe” zapotrzebowanie to takie zdarzenie, które występuje w pewnej przestrzeni czasu, przedziale czasowym, a nie jest tylko zdarzeniem o charakterze cyklicznym. Termin „niezbędne” rozumieć należy jako konieczne, nieodzowne, zapotrzebowanie na pracę na podstawie nielimitowanych umów terminowych. Powyższe rozważania prowadzą do wniosku, że wszelkie wyjątki dopuszczające zawieranie umów terminowych z pominięciem limitów powinny być interpretowane możliwie wąsko.

\section{Literalne rozumienie „obiektywnej przyczyny” potrzeb leżących po stronie pracodawcy}

Pierwsze uwagi pod adresem obowiązującej regulacji nasuwają się już po wstępnej, na poziomie językowym, lekturze przepisu. Ustawodawca wskazuje, że zawieranie umów w warunkach wyjątku jest dopuszczalne „w przypadku, gdy pracodawca wskaże obiektywne przyczyny leżące po jego stronie”. Pewien niepokój budzi konstrukcja zwrotu: „przyczyny obiektywne leżące po stronie pracodawcy”. W słowniku języka polskiego pod hasłem „przyczyny obiektywne” wyjaśniono, że:

Nie chodzi tu po prostu o „przyczynę niezależną”, ale o przyczynę niezależną od danego podmiotu, czyli subiektu. Na przykład organizator imprezy sportowej, który odwołuje ją zprzyczyn obiektywnych, chce przez to powiedzieć, że wina nie leży po jego stronie, lecz np. po stronie pogody. Takie znaczenie słowa obiektywny daje się uzasadnić etymologicznie, poza tym nawiązuje do znaczenia dobrze znanego filozofom, którzy za obiektywne uważają to, co jest niezależne od poznającego podmiotu ${ }^{4}$.

Spoglądając na omawiany zwrot ustawowy przez pryzmat znaczenia słownikowego, zyskują na znaczeniu obawy co do językowej poprawności konstrukcji zawartej w art. $25^{1} \S 4$ pkt $4 \mathrm{kp}$. Trzeba odnotować, że jeżeli przyczyna obiektywna nie jest zależna od podmiotu, bo sama w sobie jest autonomiczna, to regulacja prawna, która wymaga od podmiotu wykazania, że przyczyna obiektywna leży po jego stronie, jest z zasady błędna. Konfrontując treść przepisu ze słownikowym znaczeniem zawartego w nim zwrotu, można dojść do wniosku, że złączenie niezależnej obiektywności z subiektem,

4 M. Bańko, Przyczyny obiektywne, w: Słownik języka polskiego PWN, https://sjp.pwn.pl/poradnia/ haslo/przyczyny-obiektywne;3782.html (dostęp: 31.03.2018). 
czyni z przyczyny przyczynę subiektywną. Ponadto obowiązek łączenia przyczyny wyłącznie z osobą pracodawcy zawęża zakres zastosowania przepisu. Złączenie obiektywnej przyczyny z osobą pracodawcy poprzez sfomułowanie, że leży ona po jego stronie, wyklucza możliwość zastosowania regulacji w okolicznościach zajścia przyczyny obiektywnej - leżącej poza pracodawcą, jak np. warunki atmosferyczne.

W samym Kodeksie pracy odnaleźć można kilka przepisów, w których ustawodawca posługuje się określeniem obiektywnych: przyczyn, powodów czy kryteriów. Na tle tych przykładów językowa poprawność konstrukcji nie budzi już jednak większych obaw. I tak w art. 18 (3b) kp mowa jest o obowiązku pracodawcy wykazania, że zastosowane przez niego kryterium różnicujące było obiektywnie uzasadnione, czy wyrażony w art. 94 pkt 9 kp obowiązek stosowania przez pracodawcę obiektywnych kryteriów oceny pracowników, czyli opartych na elementach faktycznych w oderwaniu od własnych opinii, uczuć, interesów czy uprzedzeń, również w art. $129 \$ 1 \mathrm{kp}$ ustawodawca posługuje się pojęciem obiektywnych przyczyn, które mają uzasadniać zastosowanie przedłużonych okresów rozliczeniowych. W tym ostatnim przypadku za przyczyny obiektywne uznaje się w szczególności przyczyny rynkowe.

Powyżej zasygnalizowane uwagi nie dyskwalifikują zasadności dalszej analizy nad zwrotem ustawowym „przyczyny obiektywne”. Warto natomiast podkreślić, że wyrażone tutaj sugestie, mogą odpowiednio oddziaływać na sposób pojmowania zwrotu ustawowego.

\section{„Przyczyny obiektywne” w regulacji wspólnotowej i krajowej}

W czynionych rozważaniach nie wypada pominąć uregulowań wspólnotowych, albowiem są one źródłem regulacji krajowej. Omawiany przepis został wprowadzony do polskiego porządku prawnego nowelizacją z 25 czerwca 2015 r., która weszła w życie 22 lutego $2016 r{ }^{5}$ Wzorcem, obowiązującego na gruncie Kodeksu pracy, uregulowania jest Dyrektywa Rady 99/70/WE z 28 czerwca 1999 r. dotycząca Porozumienia ramowego w sprawie pracy na czas określony, zawartego przez Europejską Unię Konfederacji Przemysłowych i Pracodawców (UNICE), Europejskie Centrum Przedsiębiorstw Publicznych (CEEP) oraz Europejską Konfederację Związków Zawodowych (ETUC) ${ }^{6}$. Regulacja jest próbą dostosowania krajowego porządku prawnego do standardów wspólnotowych dotyczących przeciwdziałania nadużywaniu zatrudnienia na podstawie umów na czas określony.

5 Ustawa z dnia 25 czerwca 2015 r. o zmianie ustawy Kodeks pracy oraz niektórych innych ustaw (Dz. U. 2015.1220).

6 Dyrektywa Rady 99/70/WE z dnia 28 czerwca 1999 r., https://eur-lex.europa.eu/legal-content/PL/ TXT/?uri=CELEX\%3A31999L0070 (dostęp: 31.03.2018).

7 Jak wskazano w uzasadnieniu projektu ustawy nowelizującej, „Projektowane niniejszą ustawą zmiany w ustawie z dnia 26 czerwca 1974 r. - Kodeks pracy (Dz. U. 2014 r. 1502, 1662) zmierzają do ograniczenia nieuzasadnionego wykorzystywania umów o pracę na czas określony". Uzasadnienie do projektu ustawy z dnia 25 czerwca 2015 r. o zmianie ustawy Kodeks pracy oraz niektórych innych ustaw. Druk sejmowy nr 3321, 10 kwietnia 2015 r. 
Porozumienie ramowe ustanawia zasady ogólne i minimalne wymagania dotyczące pracy na czas określony, uznając, że szczegółowe warunki ich stosowania muszą uwzględniać rzeczywistą sytuację istniejącą w poszczególnych krajach, gałęziach i okresach ${ }^{8}$. Celem porozumienia, wyrażonym w klauzuli 1, jest: lit. b) „ustanowienie ram dla zapobiegania nadużyciom wynikającym z wykorzystywaniem kolejnych umów lub stosunków pracy zawieranych na czas określony"9.

W klauzuli 5 porozumienia, zatytułowanej „Środki zapobiegania nadużyciom”, ustawodawca wspólnotowy, wskazując środki, których zastosowanie ma zapobiegać nadużyciom wynikającym z wykorzystywania kolejnych umów o pracę lub stosunków pracy zawieranych na czas określony, posługuje się pojęciem „obiektywne powody”. Środek zapobiegania w postaci obiektywnych powodów nie został jednak zdefiniowany. Ciężar z tym związany przerzucono na państwa członkowskie. Zgodnie z motywem 17 dyrektywy:

Odnośnie pojęć użytych w Porozumieniu ramowym, ale bezpośrednio w nim niezdefiniowanych, niniejsza dyrektywa pozwala Państwom Członkowskim zdefiniować te terminy zgodnie z ich ustawodawstwem krajowym i praktyką krajową, tak jak to jest w przypadku innych dyrektyw w sprawach społecznych, używających podobnych pojęć, pod warunkiem że definicje, o których mowa, pozostają zgodne z treścią Porozumienia ramowego ${ }^{11}$.

Pomimo niewyjaśnienia przez ustawodawcę wspólnotowego znaczenia zwrotu „obiektywne powody" ${ }^{12}$ nie pozostanie on całkowicie abstrakcyjny - dookreślony wyłącznie w regulacjach krajowych. Zwrot ten był przedmiotem zainteresowania Trybunału Sprawiedliwości, dzięki temu poprzez odwołanie się do jego dorobku możliwe będzie zobrazowanie, prawidłowego sposobu pojmowania „obiektywnych przyczyn”.

Najważniejsze orzecznictwo pozwala interpretować termin jako:

(...) obiektywne powody w rozumieniu art. 5 ust. 1 lit. a) porozumienia ramowego musi być rozumiane jako odnoszące się do precyzyjnych i konkretnych okoliczności charakteryzujących

8 Załącznik do Porozumienia ramowego w sprawie pracy na czas określony. Preambuła, https://eur-lex. europa.eu/legal-content/PL/TXT/?uri=CELEX\%3A31999L0070 (dostęp: 31.03.2018).

9 Tamże, Klauzula 1.

10 Tamże, Klauzula 5. „W celu zapobiegania nadużyciom wynikającym z wykorzystywania kolejnych umów o pracę lub stosunków pracy zawieranych na czas określony Państwa Członkowskie, po przeprowadzeniu konsultacji z partnerami społecznymi, zgodnie z ustawodawstwem krajowym, układami zbiorowymi i praktyką, i/lub partnerzy społeczni, wprowadzają, o ile nie istnieją równoważne rozwiązania prawne, zmierzające do zapobiegania nadużyciom, w sposób uwzględniający potrzeby szczególnych gałęzi i/lub grup pracowników, jeden lub więcej spośród następujących środków: a) obiektywne powody, uzasadniające odnowienie takich umów lub stosunków pracy".

${ }_{11}$ Motyw 17 Dyrektywy Rady 99/70/WE... (dostęp: 31.03.2018).

12 W Kodeksie pracy widnieje zwrot „obiektywne przyczyny”, w dalszych analizach oba zwroty utożsamiamy z sobą. 
określoną działalność, a zatem mogące uzasadniać w tym szczególnym kontekście wykorzystanie kolejnych umów o pracę na czas określony ${ }^{13}$.

Pojęcie obiektywne powody w rozumieniu klauzuli wymaga, by wykorzystanie tego szczególnego rodzaju stosunków pracy, w postaci, w jakiej uregulowane są w przepisach krajowych, było uzasadnione występowaniem konkretnych okoliczności dotyczących w szczególności rozpatrywanej działalności i warunków jej wykonywania ${ }^{14}$.

(...) obiektywnym powodem uzasadniającym zawarcie umowy o pracę na czas określony są właśnie szczególne cechy uznane za charakterystyczne dla zatrudnienia w danej gałęzi, w danym zawodzie lub w danej pracy. Ponadto takim obiektywnym powodem może być również dążenie do ponownego włączenia do życia zawodowego określonych grup osób - przykładowo osób długotrwale bezrobotnych lub bezrobotnych, którzy przekroczyli określoną granicę wieku' ${ }^{15}$.

(...) Istnienie obiektywnego powodu w rozumieniu klauzuli 5 ust. 1 lit. a) porozumienia ramowego można ustalić, gdy z brzmienia lub przynajmniej z celu oraz kontekstu danego przepisu wynika expressis verbis, co stanowi cechy charakterystyczne danej gałęzi, zawodów, prac lub osób, uzasadniające nawiązywanie stosunków pracy na czas określony. W tym zakresie nie wystarcza sama okoliczność, że nawiązywanie stosunków pracy na czas określony przewidziane jest w krajowych przepisach ustawowych, wykonawczych lub administracyjnych ${ }^{16}$.

Doskonałym przykładem celu uzasadniającego zawarcie umowy expressis verbis wyrażonego w przepisach, w tym w ustawodawstwie krajowym, jest umowa o pracę na zastępstwo. Ten typ umowy w kontekście obiektywnego powodu jej zawierania także był przedmiotem analizy sądu krajowego ${ }^{17}$ i Trybunału Sprawiedliwości. Stan ten doskonale oddaje istotę dyrektywy, której celem nie jest wyeliminowanie zatrudnienia terminowego w ogóle, ale optymalizacja umów terminowych.

W kolejnych orzeczeniach Trybunału zwrócono uwagę, że:

(...) tymczasowe zapotrzebowanie na personel zastępujący, przewidziane w przepisie krajowym, takim jak rozpatrywany $\mathrm{w}$ sprawie $\mathrm{w}$ postępowaniu przed sądem krajowym, może zasadniczo stanowić obiektywny powód w rozumieniu omawianej klauzuli. Sama okoliczność, że pracodawca jest zobowiązany do korzystania z tymczasowych zastępstw w sposób powtarzalny, a nawet stały, i że

13 Punkt 69 Wyroku Trybunału Sprawiedliwości z dnia 4 lipca 2006 r. C-212/04, ZOTSiS 2006/7A-/ I-6057, ECR 2006/7A-/I-6057P.

14 Tamże, Sentencja.

15 Opinia rzecznika generalnego Juliane Kokott przedstawiona w 27 października 2005 r.; Wyrok Trybunału Sprawiedliwości z dnia 4 lipca 2006 r....

16 Opinia...; Wyrok Trybunału Sprawiedliwości z dnia 4 lipca 2006 r....

17 Nie jest dopuszczalne zawarcie umowy o pracę na zastępstwo obecnego w pracy pracownika, który zastępował pracownika nieobecnego w pracy (art. $25 \$ 1$ zdanie $2 \mathrm{kp} \mathrm{w}$ brzmieniu obowiązującym do 21 lutego 2016 r.). Wyrok Sądu Najwyższego dnia 17 maja 2016 r. II PK 99/15. SIP Lex, nr 2071114. 
tym zastępstwom można byłoby również zaradzić poprzez zatrudnienie pracowników na podstawie umów o pracę na czas nieokreślony, nie oznacza braku obiektywnego powodu w rozumieniu klauzuli 5 pkt 1 lit. a) tego porozumienia ramowego ani istnienia nadużycia w rozumieniu tej klauzuli. Jednakże przy ocenie tego, czy ponowne zawieranie umów o pracę lub nawiązywanie stosunków pracy na czas określony jest uzasadnione takim obiektywnym powodem, organy państw członkowskich powinny w ramach swoich kompetencji uwzględnić wszystkie okoliczności sprawy, w tym liczbę i łączny czas trwania umów o pracę lub stosunków pracy na czas określony zawartych w przeszłości z tym samym pracodawcą ${ }^{18}$.

Pojęcie „obiektywnych powodów” w rozumieniu rzeczonej klauzuli wymaga, aby zawarcie tego szczególnego rodzaju stosunków pracy, w takim kształcie, w jakim stanowią przepisy krajowe, było uzasadnione istnieniem konkretnych okoliczności związanych, w szczególności z działalnością, o którą chodzi i z warunkami jej wykonywania. Uzasadnieniem dla zawarcia umowy terminowej nie może być jedynie okoliczność, że odbywa się to na podstawie przepisów krajowych ${ }^{19}$.

Zgodnie z orzecznictwem pod pojęciem „obiektywnych powodów” należy rozumieć powody odnoszące się do ściśle określonych i konkretnych okoliczności charakteryzujących określoną działalność, a zatem mogące uzasadniać w tym szczególnym kontekście wykorzystanie kolejnych umów o pracę na czas określony. Okoliczności te mogą w szczególności wynikać ze szczególnego charakteru zadań, do wykonania których zawarto umowy, oraz ich swoistych cech lub w odpowiednim przypadku $\mathrm{z}$ realizacji słusznych celów polityki społecznej państwa członkowskiego ${ }^{20}$.

Przywołane orzecznictwo wspólnotowe daje ramowy obraz sposobu rozumienia obiektywnych powodów w znaczeniu pożądanym przez porozumienie. Sama w sobie klauzula 5 lit. a) nie nadaje się do bezpośredniego zastosowania, wyznacza jedynie państwom członkowskim ogólny cel polegający na zapobieganiu nadużyciom wynikającym z wykorzystywania kolejnych umów o pracę lub stosunków pracy na czas określony, pozostawiając im wybór środków do jego osiągnięcia ${ }^{21}$. Poczynione uwagi świadczą o tym, że nie jest możliwe zdefiniowanie użytego przez ustawodawcę zwrotu, konieczne jest natomiast odczytanie intencji ustawodawcy wspólnotowego wyrażonej w dyrektywie i porozumieniu jako niezbędne dla samego sposobu formułowania w ustawodawstwie krajowym przyczyn, które w konkretnej sytuacji będą obiektywnym powodem stosowania kolejnych umów terminowych. Aby jednak skutecznie zastosować intencje wyrażone

18 Wyrok Trybunału Sprawiedliwości z dnia 26 stycznia 2012 r. C-586/10, ZOTSiS 2012/1-/I-, Lex, nr 1103542, www.eur-lex.europa.eu (dostęp: 31.03.2018).

19 Postanowienie Trybunału Sprawiedliwości z dnia 24 kwietnia 2009 r. C-519/08, Lex, nr 511769, Dz. U.UE.C.2009/205/17.

20 Punkt 45 Wyroku Trybunału Sprawiedliwości z dnia 13 marca 2014 r. C-190/13, Lex, nr 1433641, ZOTSiS 2014/3-/I-.

21 Zob. teza 2. Wyroku Trybunału Sprawiedliwości z dnia 15 kwietnia 2008 r. C-268/06, Lex, nr 385339, ZOTSiS 2008/4B-/I-2483. 
w aktach wspólnotowych, konieczne jest wprowadzenie odpowiednich regulacji w ustawodawstwie krajowym. Jak podkreślono w wyroku Trybunału Sprawiedliwości

\begin{abstract}
(...) ustawodawczy lub wykonawczy przepis krajowy, który zawierałby jedynie ogólne i abstrakcyjne zezwolenie na wykorzystanie kolejnych umów o pracę na czas określony, rodzi rzeczywiste zagrożenie nadużyć tego rodzaju umów, a zatem nie jest zgodny z celem i skutecznością (effet utile) porozumienia ramowego. Okoliczność dopuszczenia, by przepis krajowy z mocy prawa i bez dodatkowych szczegółowych przesłanek uzasadniał kolejne umowy o pracę na czas określony, stanowiłaby naruszenie celu porozumienia ramowego, którym jest ochrona pracowników przed brakiem stabilności zatrudnienia, i podważałaby zasadę, w świetle której umowy na czas nieokreślony stanowią podstawową formę stosunków pracy. W szczególności stosowanie umów o pracę na czas określony wyłącznie na podstawie ogólnego przepisu ustawowego lub wykonawczego, bez uwzględnienia konkretnych okoliczności rozpatrywanej działalności, nie pozwala na wskazanie obiektywnych i przejrzystych kryteriów w celu weryfikacji, czy ponowne zawarcie takich umów w istocie służy zaspokojeniu rzeczywistej potrzeby, prowadzi do osiągnięcia realizowanego celu i jest niezbędne w tym zakresie ${ }^{22}$.
\end{abstract}

Biorąc pod uwagę powyższe, rysują się uzasadnione obawy, że polski ustawodawca w sposób zbyt ogólny sformułował wyjątek dopuszczający możliwość odstąpienia od limitów czasowych i ilościowych w stosowaniu umów o pracę na czas określony, tym samym krajowa regulacja nie oddaje istoty dyrektywy i załączonego porozumienia. Jego celem jest ustanowienie ram dla zapobiegania nadużyciom wynikającym z wykorzystywania kolejnych umów lub stosunków pracy zawieranych na czas określony ${ }^{23}$. Z tych względów w zasadzie literalne przeniesienie do Kodeksu pracy zapisów porozumienia ramowego powoduje, że polska konstrukcja nie nadaje się do praktycznego zastosowania, bo przyczyny uzasadniające zawieranie umów terminowych ponad ustaloną liczbę i wymiar nie nadają się, by je obiektywnie weryfikować, tym samym nie będzie możliwe ustalenie, co ustawodawca krajowy rozumie przez „obiektywne przyczyny”.

\title{
Obowiązek pracodawcy zawiadomienia o zawarciu umowy na czas określony z § 4 pkt 4 art. $25^{1}$ kp
}

W przypadku zawarcia umowy o pracę na czas określony z przyczyn obiektywnych na pracodawcy spoczywa obowiązek zawiadomienia o tym fakcie właściwego okręgowego inspektora pracy w ciągu 5 dni roboczych liczonych od następnego dnia po dniu zawarcia umowy (art. $25^{1} \$ 5 \mathrm{kp}$ ). Zawiadomienie, w którym należy wskazać powody zawierania tego typu umowy następuje $\mathrm{w}$ formie pisemnej lub elektronicznej. W przypadku niedopełnienia tego obowiązku przez pracodawcę ustawodawca przewidział - zgodnie

22 Wyrok Trybunału Sprawiedliwości z dnia 4 lipca 2006 r....

23 Zob. Wyrok Trybunału Sprawiedliwości z dnia 23 kwietnia 2009 r. C-379/07, Legalis 126947, ZOTSiS 2009/4A-/I-3071. 
z brzmieniem art. 281 pkt. 1a kp - karę grzywny. Kara może być więc wymierzona pracodawcy za przekroczenie pięciodniowego terminu, w ogóle za brak zawiadomienia lub za zawiadomienie w innej formie aniżeli ta określona w przepisie (czyli forma pisemna lub elektroniczna).

Zauważyć przy tym należy, że komentowany przepis nie przyznaje inspekcji pracy żadnej szczególnej roli w zakresie możliwości ewentualnego uprzedniego skontrolowania (zweryfikowania) zasadności zawierania tego typu umów. Wydaje się, iż taki rodzaj kontroli (weryfikacji) zadziałałby jako swoiste przyzwolenie dla pracodawcy na wprowadzenie nielimitowanego rodzaju umowy o pracę na czas określony. Tymczasem ustawodawca przypisuje obowiązkowi zawiadomienia funkcję statystyczno-sprawozdawczą, jak i prewencyjną, a sam udział inspektora pracy przy zawieraniu tego typu umów na czas określony pozostaje wysoce wątpliwy ${ }^{24}$.

Zgodnie z informacją zamieszczoną na stronie internetowej Państwowej Inspekcji Pracy po uzyskaniu informacji ${ }^{25}$ o zawarciu umowy terminowej bez stosowania limitów inspektor pracy ma obowiązek ustalić, czy w danym przypadku przyczyny wskazane przez pracodawcę uzasadniają zatrudnienie na takiej podstawie, czy zawarcie umowy służy zaspokojeniu rzeczywistego okresowego zapotrzebowania na pracę i czy jest niezbędne w tym zakresie, w świetle wszystkich okoliczności zawarcia umowy. Tak więc dopiero w wyniku zawiadomienia pracodawcy, o którym mowa w art. $25^{1} \$ 5 \mathrm{kp}$, inspektor pracy może wszcząć kontrolę (następczą) w celu ustalenia tych faktów oraz przestrzegania przepisów prawa pracy, co nie zmienia faktu, że szczególna umowa terminowa jest już wprowadzona do obrotu prawnego, nawet jeżeli jest bezzasadna.

Istnieją przecież w przepisach Kodeksu pracy regulacje, w których rola inspekcji pracy wyznaczona została przez ustawodawcę zdecydowanie szerzej. I tak np., zgodnie $\mathrm{z}$ treścią art. $200^{1} \$ 3 \mathrm{kp}$ wykaz prac lekkich, przy których można zatrudnić pracownika młodocianego, wymaga m.in. (uprzedniego) zatwierdzenia przez właściwego inspektora pracy. Przyjęte przez ustawodawcę, w tym zakresie, rozwiązanie pozwala ochronić młodocianych przed wykorzystywaniem ich do prac, które mogłyby zagrozić ich zdrowiu i życiu, a jednocześnie pozwala chronić pracodawcę przed konsekwencjami nielegalnego zatrudnienia tej grupy pracowników. Ustawodawca, dopuszczając wyjątki od przyjętych reguł w zatrudnieniu pracowników młodocianych, jednocześnie - poprzez przyznanie szerszych kompetencji inspekcji pracy - wzmacnia ochronę. Jednak przy terminowych umowach szczególnych jako wyjątkach od limitowanych terminowych umów o pracę kompetencje właściwego okręgowego inspektora pracy nie zostały określone w sposób precyzyjny, ale za to zostały mocno ograniczone. Zastanawia to, tym bardziej że projekt ustawy o zmianie Kodeksu pracy przewidywał uprzednio poszerzenie kompetencji

24 J. Stelina, w: Kodeks pracy. Komentarz, wyd. 3, A. Sobczyk (red.), Warszawa 2017, s. 142; Tenże, Nowa koncepcja umowy o pracę na czas określony, Państwo i Prawo 2015, 11, s. 49-50.

25 Zob. Ł. Pisarczyk, Nowy model zatrudnienia terminowego w prawie pracy? - czesść 1, Monitor Prawa Pracy 2016, 4, s. 181, gdzie autor wskazywał na propozycje i sposoby skutecznego informowania PIP o „obiektywnych przyczynach” leżących po stronie pracodawcy. 
Państwowej Inspekcji Pracy w tym zakresie, ale ostatecznie tak się nie stało. Projektowane przepisy zmieniające ustawę o Państwowej Inspekcji Pracy i ustawę Kodeks postępowania cywilnego przyznawały inspekcji pracy prawo wnoszenia powództw, a za zgodą osoby zainteresowanej uczestnictwo $\mathrm{w}$ postępowaniu sądowym o ustalenie, że w związku $\mathrm{z}$ niedopełnieniem przesłanek uzasadniających zawarcie umowy na czas określony została zawarta umowa o pracę na czas nieokreślony ${ }^{26}$.

Konstruując wniosek de lege ferenda, należy wskazać, że skuteczniejsza ochrona przed nadużywaniem stosowania nielimitowanych umów o pracę będzie przy uprzednim weryfikowaniu przez inspekcję pracy owych obiektywnych przyczyn uzasadniających zawieranie tego rodzaju umów. Samo zawiadamianie o fakcie ich zawarcia nie tworzy żadnej ochrony. Wydaje się, iż przyjęte aktualnie przez ustawodawcę rozwiązanie może stanowić zagrożenie nie tylko dla samego pracownika, który decydując się na umowę terminową, pozbawia się stabilizacji zatrudnienia, lecz również i dla pracodawcy, który $\mathrm{w}$ trakcie trwania terminowej umowy o pracę, a szczególnie po upływie „bezpiecznych” 33 miesięcy, może w każdej chwili spodziewać się zakwestionowania przyczyny zawarcia tego typu umowy, co może ostatecznie doprowadzić do zakwalifikowania jej jako umowy bezterminowej. Owa kwalifikacja i ocena umowy - w świetle obowiązującego stanu prawnego - będzie dokonywana przez sąd pracy. Nałożony na pracodawcę obowiązek informacyjny nie gwarantuje w sposób efektywny ochrony. Natomiast zdecydowanie bardziej przyczynia się do biurokratyzacji, dodatkowo obciążając zarówno pracodawcę, jak i inspekcję pracy ${ }^{27}$.

Zwrócić należy również uwagę, iż analizowany przepis art. $25^{1} \mathrm{kp}$ nie określa - w żadnym z przypadków wskazanych $\mathrm{w} \$ 4$ - skutków bezzasadnego zawarcia nielimitowanej umowy o pracę na czas określony. Zarówno w sytuacji, gdy pracodawca wskazał nieprawdziwą przyczynę albo przyczynę realną, ale nieuzasadniającą zawarcia szczególnej umowy terminowej, ustawodawca nie określił, co z taką umową terminową dalej się stanie. Należałoby wówczas przyjąć, że umowa taka traktowana jest jak zawarta na czas nieokreślony z tym, że nie dzieje się tak z mocy prawa. Dochodzenie tego możliwe będzie albo przez samego pracownika, który zakwestionuje istnienie obiektywnej przyczyny leżącej po stronie pracodawcy i w trybie art. 189 Kodeksu postępowania cywilnego (kpc) wystąpi o ustalenie, iż łącząca go z pracodawcą umowa jest zawarta na czas nieograniczony lub też przy okazji rozstrzygania sporu z pracodawcą np. o niedopuszczenie do pracy lub o brak zasadności wypowiedzenia umowy o pracęe podważy charakter takiej umowy terminowej. Powstaje również pytanie, czy uprawnionym do wystąpienia z powództwem przeciwko pracodawcy pozostaje także inspektor pracy w sytuacji, gdy uzna, że wskazana przez pracodawcę obiektywna przyczyna nie uzasadnia uchylenia

26 A. Dral, Zatrudnienie na podstawie umów terminowych $w$ świetle nowelizacji k.p. $z 25$ czerwca 2015 r., Studia z Zakresu Prawa Pracy i Polityki Społecznej, K.W. Baran (red.), Kraków 2016, s. 33.

27 L. Mitrus, Projekt nowelizacji Kodeksu pracy dotyczacy umów terminowych, Monitor Prawa Pracy 2015, 6, s. 291.

28 J. Stelina, w: Kodeks pracy. Komentarz. 
zasad ogólnych dotyczących zatrudnienia terminowego. Zgodnie z brzmieniem art. $63^{1}$ kpc w sprawach o ustalenie istnienia stosunku pracy inspektorzy pracy mogą wytaczać powództwa na rzecz obywateli. Tak więc, inspektor pracy pozostaje uprawniony do wytoczenia powództwa o ustalenie, że umowa terminowa w związku z niespełnieniem przesłanek $\mathrm{z}$ art. $25^{1} \S 4 \mathrm{kp}$ zawarta została na czas nieokreślony ${ }^{29}$.

\section{Moment zaistnienia i konieczność uzasadniania ustania obiektywnej przyczyny leżącej po stronie pracodawcy}

Kolejnymi, niezwykle istotnymi zagadnieniami w kontekście zawarcia z pracownikiem nielimitowanych umów terminowych, wymagającymi omówienia pozostają: moment zaistnienia (wystąpienia) obiektywnych powodów po stronie pracodawcy oraz konieczność uzasadnienia przez pracodawcę ustania obiektywnej przyczyny, co wiąże się z kolei z możliwością rozwiązania umowy terminowej.

Zgodnie z brzmieniem art. $25^{1} \S 4$ pkt $4 \mathrm{kp}$ pracodawca powinien wskazać obiektywne przyczyny leżące po jego stronie. Powstaje więc pytanie, $w$ jakim momencie powinno wskazanie takie nastąpić. Czy już przy zawieraniu z pracownikiem terminowej umowy o pracę, czy możliwe jest wskazanie później, kiedy „zwykła” umowa terminowa już obowiązuje. Biorąc pod uwagę treść art. $29 \$ 1^{1} \mathrm{kp}^{30}$, wskazanie takie następuje przez określenie $\mathrm{w}$ umowie o pracę celu lub okoliczności zawarcia terminowej umowy o pracę z powodu obiektywnych przyczyn leżących po stronie pracodawcy, czyli już przy zawieraniu umowy. Wskazanie pracodawcy (informacja o obiektywnych przyczynach) nie jest oświadczeniem woli, lecz oświadczeniem wiedzy i dlatego podlega weryfikacji z punktu widzenia jej prawdziwości, czyli w zasadzie może być podważane rzeczywiste istnienie okoliczności faktycznych wskazanych jako przyczyna mająca uzasadniać zawarcie umowy na czas określony. W przypadku ustalenia prawdziwości informacji o istnieniu tych okoliczności dalsza jej weryfikacja polega na ocenie prawnej, czy ustalone okoliczności spełniają wymagania przewidziane w art. $25^{1} \$ 4 \mathrm{kp}$. Co do zasady to pracodawca proponuje zamieszczenie w umowie omawianej informacji i on ustala jej treść, tak więc podpis pracownika pod umową oznacza - w zakresie tej informacji - jedynie potwierdzenie zapoznania się z nią. Przy „obiektywnych przyczynach” leżących po stronie pracodawcy trudno jest wymagać od pracownika, aby je znał i swoim podpisem potwierdził ich istnienie. Jedyne, co pracownik potwierdza, to fakt, że zostały mu przedstawione informacje uzasadniające zawarcie umowy terminowej bez limitów. Z zamieszczenia w umowie informacji o przyczynie zawarcia jej na czas określony skutki prawne w postaci niestosowania do niej limitów, przewidzianych $w$ art. $25^{1} \S 1 \mathrm{kp}$, i tak

29 A. Ludera-Ruszel, Ocena nowej regulacji umowy o pracę na czas nieokreślony - pozytywny kierunek zmian czy utrzymanie status quo?, Praca i Zabezpieczenie Społeczne 2016, 2, s. 30; Ł. Pisarczyk, Nowy model zatrudnienia..., s. 181.

30 Dodany do kodeksu przez ustawę nowelizującą z dnia 25 czerwca 2015 r. 
wywodzi pracodawca, który zgodnie z art. 6 Kodeksu cywilnego (kc) w związku z art. $300 \mathrm{kp}$ jest obciążony dowodem jej prawidłowości. Niezamieszczenie w umowie na czas określony, spełniającej przesłanki przewidziane $\mathrm{w}$ art. $25^{1} \$ 4 \mathrm{kp}$ dla umowy obiektywnie uzasadnionej, informacji wymaganej przez art. $29 \$ 1^{1} \mathrm{kp}$ niewątpliwie stanowi naruszenie prawa. Wobec braku bezpośredniej regulacji w Kodeksie pracy tej kwestii należy przyjąć, że podmiotem odpowiedzialnym będzie pracodawca, bo to na niego ustawodawca nałożył obowiązek informacyjny. Jego pominięcie w umowie będzie stanowić naruszenie, ale nie zmieni charakteru prawnego umowy, który zostaje wyznaczony przez rzeczywisty stan rzeczy, podlegający kwalifikacji prawnej według art. $25^{1} \S 1$ lub $\$ 4 \mathrm{kp}^{31}$. Jeżeli więc pracodawca nie zamieści w umowie omawianej informacji - choć leży to w jego interesie - to oczywiście nie zostaje pozbawiony możliwości udowodnienia tego, że umowa jest obiektywnie uzasadniona (a precyzyjnie była obiektywnie uzasadniona w momencie jej zawierania z pracownikiem). Wykazywanie już w trakcie trwania procesu przez pracodawcę charakteru umowy i jednoczesne uzasadnianie, dlaczego nie dopełnił on obowiązku informacyjnego, może nasuwać podejrzenie, że jest to czynione wyłącznie na użytek procesu, co w praktyce utrudni pracodawcy udowodnienie zasadności zawarcia szczególnej terminowej umowy o pracę.

Wskazanie obiektywnych przyczyn powinno następować już przy zawieraniu umowy, choć wymóg ten nie został wyraźnie sformułowany przez ustawodawcę. Dopuszczenie możliwości wprowadzenia do umowy o pracę klauzuli obiektywnych przyczyn, ale już po jej zawarciu, doprowadziłoby do całkowitego zachwiania stabilności zatrudnienia pracownika i pozbawienia go ochrony. Pracodawca przy zawieraniu umowy o pracę pozostaje w obowiązku wskazać, że zawierana z pracownikiem umowa jest uzasadniona z konkretnie wymienionych powodów. Z uwagi na to, że ustawodawca szeroko otworzył pracodawcy możliwość powoływania się na „obiektywne powody”, mogą do nich należeć różnorakie okoliczności m.in. związane z charakterem realizowanych przez pracodawcę zadań, ale również i te związane z okresowym wzrostem zapotrzebowania na pracę ${ }^{32}$. W doktrynie wskazano także, iż ważnym czynnikiem wskazującym na obiektywne uzasadnienie zatrudnienia terminowego jest zewnętrzne finansowanie działalności pracodawcy, które zostało czasowo ograniczone ${ }^{33}$. Strony umowy nie mogą jednak uznawać, że umowa terminowa jest obiektywnie uzasadniona wbrew jej rzeczywistemu charakterowi ${ }^{34}$. Nawet jeżeli $w$ treści umowy znalazło się takie postanowienie - zgodnie $\mathrm{z}$ art. $25^{1} \$ 4 \mathrm{kp}$ - to i tak, zdaniem $Ł$. Pisarczyka, umowa traktowana będzie jako terminowa umowa o pracę podlegająca limitowaniu. W doktrynie prezentowany jest

${ }^{31}$ K. Jaśkowski, Komentarz zaktualizowany do art. 25ㄹ, LEX.

32 M. Rylski, Przeciwdziałanie nadużywaniu umów o pracę na czas określony po nowelizacji Kodeksu pracy, Praca i Zabezpieczenie Społeczne 2016, 11, s. 23.

33 Tak Ł. Pisarczyk, Nowy model zatrudnienia..., s. 179, poglądu tego nie podziela M. Rylski, Przeciwdziałanie nadużwaniu..., s. 23-24.

34 Ł. Pisarczyk, Nowy model zatrudnienia..., s. 180-181. 
również pogląd odmienny ${ }^{35}$, zgodnie z którym umowa taka powinna być (od momentu zawarcia) uznana za zawartą na czas nieokreślony.

Tak więc, wystąpienie obiektywnych powodów i wskazanie obiektywnych przyczyn leżących po stronie pracodawcy, a uzasadniających zawarcie terminowej (nielimitowanej) umowy o pracę, należy oceniać w momencie zawierania z pracownikiem takiej umowy. Ewentualne późniejsze zaistnienie obiektywnych powodów lub też ich ustanie nie może mieć wpływu na typ zastosowanej umowy o pracę na czas określony.

W momencie ustania obiektywnych przyczyn leżących po stronie pracodawcy ( $\$ 4$ pkt 4 art. $25^{1} \mathrm{kp}$ ) albo po odpadnięciu celów, o których mowa $\mathrm{w} \$ 4$ pkt. 1-3 art. $25^{1} \mathrm{kp}$ uzasadniających zawarcie nielimitowanej terminowej umowy o pracę, konieczne pozostaje jej wypowiedzenie. $\mathrm{W}$ przeciwnym razie $\mathrm{z}$ dniem ustania powodu, dla którego umowa terminowa nielimitowana była zawierana, dochodzi do przekształcenia jej szczególnego rodzaju w zwykły, a tym samym będzie ona podlegała ograniczeniom, o których mowa w $\$ 1$ analizowanego przepisu ${ }^{36}$.

\section{Uwagi końcowe}

Przedstawiona analiza problemu w zakresie „obiektywnych przyczyn” leżących po stronie pracodawcy jako przyczyny warunkującej zawarcie szczególnej (nielimitowanej) umowy terminowej o pracę skłania do refleksji, iż wprowadzona regulacja pozostaje wysoce niedoskonała, co stwarza problemy nie tylko na poziomie wykładni, lecz również na poziomie praktycznym. Po pierwsze, $z$ uwagi na posłużenie się przez ustawodawcę klauzulą generalną i pojęciami nieostrymi, po drugie, z uwagi na nieprecyzyjne określenie w ustawie kompetencji właściwego okręgowego inspektora pracy, który wprawdzie może dokonać kontroli (weryfikacji) zawartej umowy obiektywnie uzasadnionej, ale dopiero post factum. Rozwiązanie takie tworzy w zasadzie ochronę jedynie na papierze, albowiem w rzeczywistości obiektywne przyczyny uzasadniające zawarcie tego typu umowy mogą nie istnieć, sama umowa zaś będzie już funkcjonowała w obrocie prawnym. Sytuacja taka nie zawsze musi wiązać się z celowym działaniem pracodawcy nastawionym na obejście prawa. Można bowiem wyobrazić sobie, że pracodawca nieprawidłowo ustali (określa) obiektywnie przyczyny, które umożliwiają zawarcie z pracownikiem umowy bez limitów. Jest to jak najbardziej możliwe, bo przecież nie każdy pracodawca będzie wiedział, iż wyjątki powinny być interpretowane zgodnie z ogólną regułą wykładni zawężającej, a potrzeba zatrudnienia wynikająca $\mathrm{z}$ obiektywnych przyczyn powinna być również oceniona przez pryzmat dwóch przesłanek ogólnych, o których mowa jest $\mathrm{w}$ treści art. $25^{1} \$ 4 \mathrm{kp}$. Tymczasem po upływie bezpiecznego dla pracodawcy okresu 33 miesięcy pracownik postanawia zakwestionować ten szczególny rodzaj umowy. Taka sytuacja, przy nieumyślnym działaniu pracodawcy sprawia, iż stosunek pracy przekształci

35 Zob. J. Stelina, Nowa koncepcja..., s. 49-50.

36 J. Stelina, w: Kodeks pracy. Komentarz, s. 142. 
się na bezterminowy, a pracodawca zmuszony pozostanie nie tylko do wypowiedzenia pracownikowi umowy o pracę, ale również do podania przyczyny wypowiedzenia umowy, a ostatecznie może doprowadzić do konieczności wypłaty pracownikowi odprawy. De lege ferenda umożliwienie pracodawcy, przed zawarciem tego typu umowy, weryfikacji istnienia obiektywnych przyczyn uzasadniających zawarcie umowy szczególnej dokonywanej przy udziale inspekcji pracy stworzyłoby faktyczną - a nie jedynie iluzoryczną - ochronę przed nadużyciami.

Zresztą z literalnego brzmienia art. $25^{1} \mathrm{kp}$ wynika, że wymóg kierowania się obiektywnymi przyczynami będącymi uzasadnieniem zawierania umów na czas określony został sformułowany tylko względem tych umów, które nie podlegają limitom. Stan taki oceniany jest przez doktrynę $e^{37}$ krytycznie, albowiem nie uwzględnia on charakteru umowy na czas określony, jej celu oraz społeczno-gospodarczego przeznaczenia.

\section{Bibliografia}

Bańko M., Przyczyny obiektywne, w: Słownik języka polskiego PWN, https://sjp.pwn.pl/poradnia/ haslo/przyczyny-obiektywne;3782.html (dostęp: 31.03.2018).

Daszyńska-Ciborowska A., Zagadnienie kauzalności umów o prace na czas określony w świetle dotychczasowych $i$ znowelizowanych przepisów, w: Terminowe umowy o pracę: aktualne problemy zatrudnienia, M. Mędrala (red.), Warszawa 2017.

Dral A., Zatrudnienie na podstawie umów terminowych w świetle nowelizacji k.p. $z 25$ czerwca 2015 r., Studia z Zakresu Prawa Pracy i Polityki Społecznej, K.W. Baran (red.), Kraków 2016.

Dyrektywa Rady 99/70/WE z dnia 28 czerwca 1999 r., https://eur-lex.europa.eu/legal-content/ PL/TXT/?uri=CELEX\%3A31999L0070 (dostęp: 31.03.2018).

Jaśkowski K., Komentarz zaktualizowany do art. $25^{1}$. LEX.

Ludera-Ruszel A., Ocena nowej regulacji umowy o pracę na czas nieokreślony - pozytywny kierunek zmian czy utrzymanie status quo?, Praca i Zabezpieczenie Społeczne 2016, 2.

Mitrus L., Projekt nowelizacji Kodeksu pracy dotyczący umów terminowych, Monitor Prawa Pracy 2015, 6.

Opinia w sprawie rzadowego projektu ustawy o zmianie ustawy Kodeks pracy oraz niektórych innych ustaw Sądu Najwyższego Biura Studiów i Analiz z dnia 15 maja 2015 r., http://orka. sejm.gov.pl/Druki7ka.nsf/0/EF78323E83FAD463C1257E4D002211D7/\%24File/3321-003. pdf (dostęp: 31.03.2018).

Opinia rzecznika generalnego Juliane Kokott przedstawiona w dniu 27 października 2005 r.

Pisarczyk Ł., Nowy model zatrudnienia terminowego w prawie pracy? - część 1, Monitor Prawa Pracy 2016, 4.

${ }^{37}$ Zob. A. Daszyńska-Ciborowska, Zagadnienie kauzalności umów o pracę na czas określony w świetle dotychczasowych i znowelizowanych przepisów, w: Terminowe umowy o pracę: aktualne problemy zatrudnienia, M. Mędrala (red.), Warszawa 2017, s. 77-94. 
Porozumienie ramowe w sprawie pracy na czas określony. Preambuła, https://eur-lex.europa.eu/ legal-content/PL/TXT/?uri=CELEX\%3A31999L0070 (dostęp: 31.03.2018).

Postanowienie Trybunału Sprawiedliwości z dnia 24 kwietnia 2009 r. C-519/08, Lex, nr 511769, Dz. U.UE.C.2009/205/17.

Rylski M., Przeciwdziałanie nadużywaniu umów o pracę na czas określony po nowelizacji Kodeksu pracy, Praca i Zabezpieczenie Społeczne 2016, 11.

Stelina J., w: Kodeks pracy. Komentarz, wyd. 3, A. Sobczyk (red.), Warszawa 2017.

Stelina J., Nowa koncepcja umowy o prace na czas określony, Państwo i Prawo 2015, 11.

Ustawa z dnia 26 czerwca 1974 r. Kodeks pracy (Dz. U. 2018, 108).

Ustawa z dnia 25 czerwca 2015 r. o zmianie ustawy Kodeks pracy oraz niektórych innych ustaw (Dz. U. 2015.1220).

Uzasadnienie do projektu ustawy z dnia 25 czerwca 2015 r. o zmianie ustawy Kodeks pracy oraz niektórych innych ustaw. Druk sejmowy nr 3321, 10 kwietnia 2015 r.

Wyrok Sądu Najwyższego dnia 17 maja 2016 r. II PK 99/15. SIP Lex, nr 2071114.

Wyrok Trybunału Sprawiedliwości z dnia 23 kwietnia 2009 r. C-379/07, Legalis, 126947, ZOTSiS 2009/4A-/I-3071.

Wyrok Trybunału Sprawiedliwości z dnia 26 stycznia 2012 r. C-586/10, ZOTSiS 2012/1-/I-, Lex, nr 1103542, www.eur-lex.europa.eu (dostęp: 31.03.2018).

Wyrok Trybunału Sprawiedliwości z dnia 4 lipca 2006 r. C-212/04, ZOTSiS 2006/7A-/ I-6057, ECR 2006/7A-/I-6057P.

Wyrok Trybunału Sprawiedliwości z dnia 13 marca 2014 r. C-190/13, Lex, nr 1433641, ZOTSiS 2014/3-/I-.

Wyrok Trybunału Sprawiedliwości z dnia 15 kwietnia 2008 r. C-268/06, Lex, nr 385339, ZOTSiS 2008/4B-/I-2483. 